\title{
The Cinematic Cowboy in Africa: Identities and the Western Genre
}

\begin{abstract}
This article identifies instances in Africa in which the western genre and specifically the figure of the cowboy is appropriated and adapted to local circumstances. It opens with a brief excursion into the western's influence on African cinema, focusing primarily on Bamako (2016). The article develops a brief discussion of the potentials and pitfalls of comparative research in relation to Africa and proposes that focusing on a specific genre such as the western, is a useful additional element in adopting modes of comparative research. The article focuses on examples drawn from different parts of the continent including the Democratic Republic of Congo, Tanzania and Southern Africa. Finally, it draws conclusions on the potential of future research focusing on the cinematic cowboy and his appropriation into the lives of African audiences.
\end{abstract}

\section{Keywords}

Africa; audiences; cinema; cowboys; western genre

\section{Introduction}

The film Bamako (2006), set in a courtyard in Bamako, the capital city of Mali, includes a short, mock, 'spaghetti' western within the film proper entitled Death in Timbuktu. At a screening and Q\&A event held at the National Film Theatre in London in 2014, a member of the audience asked the filmmaker, Abderrahmane Sissako, why he had inserted this short film. His reply was that he had seen many westerns as a boy growing up in Africa and had always wanted to make one himself. Sissako performs within the short western credited as Dramane Bassaro, the name of the character he plays in his earlier film, La vie sur terre (Life on Earth, 1998). The celebrated actor, Danny Glover, whose production company, Louverture, produced the film, acts as the 'lone ranger' character. As well as 
being an opportunity for Sissako to make his own western and to perform the role of a cowboy himself, the short western, and its specific plot, plays an especially critical role. ${ }^{1}$

The film as a whole is based on a fictitious court case, in which the people of Mali take the International Monetary Fund (IMF) and the World Bank to court. A series of local people provide witness to their views before a presiding judge and other legal professionals acting for both the prosecution and the accused. The witness statements in the trial critique the globalisation goals of the IMF and the World Bank and particularly the Structural Adjustment Programmes, to which countries like Mali have had to sign up resulting in severely destructive effects on locally-driven economies. Sissako's western is filmed on location in Timbuktu, his own version of the sandy southern Spain or Italian equivalent of the Wild West representing the locations of Italian 'spaghetti' westerns. Indeed in Sissako’s 'film lesson,' published in Africultures in 2003 (before he made Bamako), he comments that '[s]paghetti westerns have marked my entire film culture. They were very important for me. ${ }^{2}$

While apparently 'playing' with cowboy imagery and characterisation, Sissako simultaneously constructs a powerful, adjunctive allegory to Bamako's wider critique of globalisation. The first image in Death in Timbuktu represents the lone ranger (Glover) in full cowboy regalia, including the

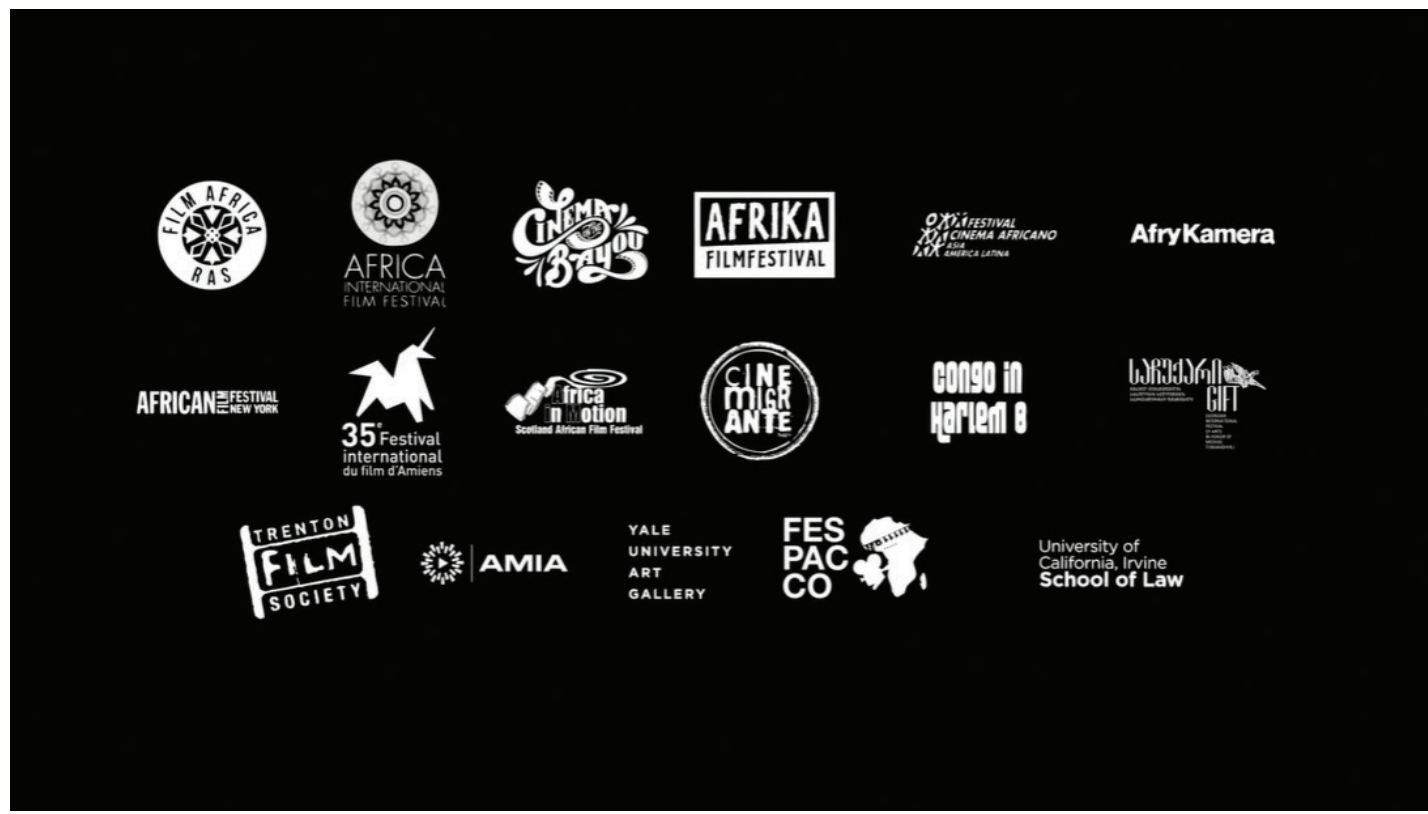

Figure 1. The "Death in Timbuktu" section from the film Bamako (Abderrahmane Sissako 2006). 
wide-brimmed hat, long overcoat, bullets strung across his chest, alongside his horse at the foot of a sandy dune beside a lake. Four cowboys, on horses and dressed in typical cowboy attire, enter Timbuktu, where the remainder of the short is filmed. In a gun-toting shooting scene where local people are the target, one of the cowboys (Zeka Laplaine) boasts of killing two women with one bullet rather than simply one, over-extending his self-congratulatory laughter shown in increasingly close shots. The lone ranger shoots and kills him from a viewpoint above the streets.

The short film's insertion into the wider film is both framed and interrupted by images of the television audience in the courtyard where the court case takes place by day and where the television is positioned in the evening after the day's proceedings. Initially there are technical problems with the service, for which the anchor woman apologises, giving a nod to real-life hitches that audiences might expect. At the point where Laplaine laughs with his fellow cowboys about killing two women with one bullet, the image cuts away to the audience and a close-up view of a boy enraptured. A short while later, with Laplaine's laughter still dominating, there is a further cutaway to the audience and a young girl laughing. Glover then takes up his position to shoot Laplaine and executes his shot. The effect of this is twofold, on the one hand Sissako points to the question of audience identification with the figure of the cowboy and at the same time he clearly delineates between the good cowboy, in the form of the lone ranger, and the bad cowboy, Laplaine, who randomly shoots to kill. The short film is clearly on the side of the lone ranger, taking up the cause of justice, and thus acts as a form of allegory for the wider film's critique of the IMF and the World Bank's policies. But how the courtyard audience of Death in Timbuktu 'reads' the short film and the extent to which the overt reading is one of complicity in its own demise remains an open question. ${ }^{3}$

Just over 100 years before Sissako's production of Bamako and Death in Timbuktu, the image of Buffalo Bill was already introducing the figure of the cowboy to Africa. In South Africa for example, the first 'showing' of 'moving pictures' in South Africa courtesy of an Edison kinetoscope in 1895 included 'Buffalo Bill in one of his quick-firing exhibitions.'4 This was to a small select group of 'literary and scientific gentlemen, ${ }^{5}$ but two weeks later it was opened to the public in Henwood's Arcade in Johannesburg. The same image of Buffalo Bill, who the South African film historian Thelma Gutsche describes as 'Colonel Cody - the first real movie star,' could be seen 'galloping jerkily about firing at a glass ball with a Colt repeating rifle. ${ }^{6}$ In all likelihood the audiences for these exhibitions were white, although one can speculate as to the street audiences that might have seen the city centre exhibition in a shop window. 
The ubiquity of seeing westerns across different parts of Africa and their effects on African audiences is increasingly coming to light in scholarly publications focusing on examples drawn from a range of countries. In the light of this issue's focus on comparative approaches, it is thus a valuable exercise to identify scholarship related to different instances where westerns have been influential in Africa. This embryonic investigation is hardly one that can be called 'comparative' as such, but it nevertheless raises several issues relevant to the delineation of comparative research modes within 'new cinema history.' While this article points towards a 'universalising' mode of research in that it focuses on different geographical areas and different methodologies, it also represents an interest in a single genre, the western. ${ }^{7}$ It therefore incorporates an additional, defining, element by focusing specifically on a genre of films rather than films in general. Two issues are important to comment upon.

First, the matter of space, since in this article I purposely roam across different places and spaces, considering scholarship from any part of Africa. This continental focus is in part the result of recent scholarly publications from different parts of Africa. More broadly, it emanates from the need to excavate findings specifically about Africa. This continent of over fifty countries is largely absent from scholarly histories of cinema, although there has been pioneering scholarship on some regions and there is a growing body of continuing research.

Second, the wide-ranging excavation I have accomplished for this article, including anecdotal instances as well as in-depth studies, focuses specifically on the western genre. My interest in doing so first arose in my research on cinema-going in District Six, Cape Town, where I had access to life histories of former residents, in which more than seventy percent of residents referred to the cinema or cinema-going experiences. Some of these oral histories make reference to westerns or gangster films and their assimilation into everyday life in District Six. ${ }^{8}$ The western (and gangster) genre has struck me as a fertile space for ongoing research into cinema-going and its cultural effects, evident in cinema-goers' emulation of cinema-inspired clothing styles and fashions, as well as behaviours, and moreover to understand these within the wider historical and socio-political contexts of South Africa.

The research for this article exposed more evidence of the effects of westerns and gangsters than I had expected and perforce I chose to focus on westerns, in part because the western genre predates the gangster genre. This was a wise choice as the segue from western-inspired styles and behaviours to those emulating gangster films is blurred in many instances. While western-inspired dress codes for example are the explicit or implicit shared fashion style of a group, its behaviours 
might emulate the gangland predilections for power and authority outside of the law. The 'outlaw' figure first produced in the western, is later also produced in the gangster film, a figure that has been a key influence on African audiences under colonialism and apartheid. ${ }^{9}$

The choice of a genre for historical research, and particularly the western, could provide a solution to some of the problems that comparative research raises, especially where there is not yet enough research on a specific region. Much depends on available archival resources as well as options for innovative research methods, including oral histories or extant life histories that might reveal references to the cinema or cinema-going. Burns elaborates some of the problems with the potential for comparing the British West Indies with other regions (in this issue) and concludes that more research 'will need to be done before it can be usefully compared to other regions.' He does however offer some ways in which comparisons could be made between the British West Indies and South Africa. Daniela Treveri Gennari, Lies Van de Vijver and Pierluigi Ercole discuss the challenges of 'cross-national research' (in this issue), which are pertinent also to research ventures in Africa. Matched equivalences of data will not be available to researchers of African audiences without bespoke, funded research projects such as those developed in Europe. This does not have to mean however, that no comparisons can be made.

In the next section I identify some recent scholarship as well as some earlier examples that expose how films in the western genre have shaped social and cultural identities in different parts of Africa.

\section{Scholarship on cowboys in Africa}

In Reel Pleasures: Cinema Audiences and Entrepreneurs in Twentieth-Century Urban Tanzania (2018), Laura Fair discusses the influence of the cowboy figure in Tanzania. This raises important matters vis-à-vis the influence of Hollywood and American westerns that, she suggests, were 'outgunned in Tanzania by their Italian counterparts.' 10 The Italian star, Giuliano Gemma, popularised through Italian westerns, was favoured in the 1960s and 1970s. He topped the bill in Fair's surveys as the 'most frequently named Western actor.'11 Lee Van Kleef and Clint Eastwood were 'household names' but this was down to their roles in Sergio Leone's Italian westerns. ${ }^{12}$ In terms of the effects of the popularity of Italian westerns, the film My Name is Pecos (1967), in which Giuliano Gemma plays the role of Pecos, spawned a generation of young men who wore bell-bottomed 'Pecos pants.' Fair provides a 
sense of the political context of this period too, both in terms of the reasons behind adoption of the 'Pecos pants' and the exceptionally harsh consequences for some who wore them and who were arrested, convicted and sent away for re-education and hard labour. ${ }^{13}$

In Tropical Cowboys: Westerns, Violence, and Masculinity in Kinshasa (2016), Ch. Didier Gondola focuses on the Bills in Kinshasa, Democratic Republic of the Congo (DRC). These were gangs of young men, and sometimes women, who modelled themselves on Buffalo Bill in his cowboy films of the 1950s, emulating his attire of checked shirt, necktie, hat and pointed shoes. Gondola locates the rise of Billism in Kinshasa in the historical context of what was known as the Belgian Congo before its independence in 1960, and the imbrications of the figure of Buffalo Bill within it. He asserts that historically the popularity of this 'properly mythic cowboy-frontiersman hero' was driven less through his exploits on the frontier and more so through his stage acts that included re-enactments of his screen persona. ${ }^{14}$ Cody took these acts all over the USA and Europe before his death in 1917. His ability to blur reality with fiction - 'Cody the man, Buffalo Bill the hero' - was apparently key to his legendary status and his embodiment of masculinity. ${ }^{15}$

The missionaries who were 'ubiquitous' in Kinshasa, would themselves have witnessed the Buffalo Bill shows and films in their early years in Belgium. ${ }^{16}$ These missionaries, Gondola suggests, may have even perceived similarities between King Leopold II and Buffalo Bill, seeing him as a kind of 'tropical' Buffalo Bill, 'the embodiment of colonial masculinity, selflessly opening terra nullius to civilization, erecting symbols of modernity where stultified tribes had once languished, and showering the wretched natives with Europe's cultural largesse. ${ }^{17}$ It was through missionaries that the Buffalo Bill character was introduced to 'Congolese youth.'18 By the late 1940s 'Africans from all walks of life were exposed to film. ${ }^{19}$

Young audiences, Gondola contends, 'parlayed their vision of the Far West from the screen into the street,' creating what he calls 'a unique hybrid blend. ${ }^{20}$ This idea provides an excellent descriptor not only for the case of Kinshasa's Bills but for other exemplars where African audiences appropriated the figure of the cowboy (and/or gangster) and shaped its local rendition through adopting behaviours and fashion styles in the same way as the Bills 'conflated the Hollywood version of the drifting cowboy with local elements of manhood and fashioned township gangs after frontier posses. ${ }^{21}$

In Angola, 'cowboiadas' or American westerns and Asian kung-fu films that 'played mostly at the few cinemas in black neighborhoods' were, Marissa Moorman reports, most popular in the 1950s to the 1970s. ${ }^{22}$ Moorman's ambitious article 'think[s] the relationship between cinema and the nation' 
through a discussion focusing on the history of cinema in Angola and the production of revolutionary films in Angola primarily focused on Sambizanga (1972). ${ }^{23}$ This combination of histories is exceptionally fruitful and opens up a range of important issues. Citing interviews with local interlocutors, including a 'prominent nationalist figure,' Mário Pinto de Andrade, Moorman identifies a key issue that proffers a valuable means of framing some of the deeper questions that the appropriation of the cowboy figure raises. This is the matter of audience identification, which she considers through a discussion of Ella Shohat and Robert Stam's (1994) reflections on the ambivalent, 'fissured colonial spectator.' In Moorman's reading of Shohat and Stam's scholarship, point-of-view conventions in both colonial films and westerns push this spectator to identify with 'imperial agents' and a 'colonialist perspective.' Shohat and Stam maintain, for example, that point-of-view conventions prevent identification with 'the Indians' in films of the western genre.

Moorman cites the comments of her Angolan interlocutor, de Andrade, whose political standing might otherwise suggest that he would not identify with the cowboy figure, thus revealing the complexity of audience identifications not only with the western genre but also more generally with 'American cinema'. He comments, for example, on how he looked up to his brother and cousins and

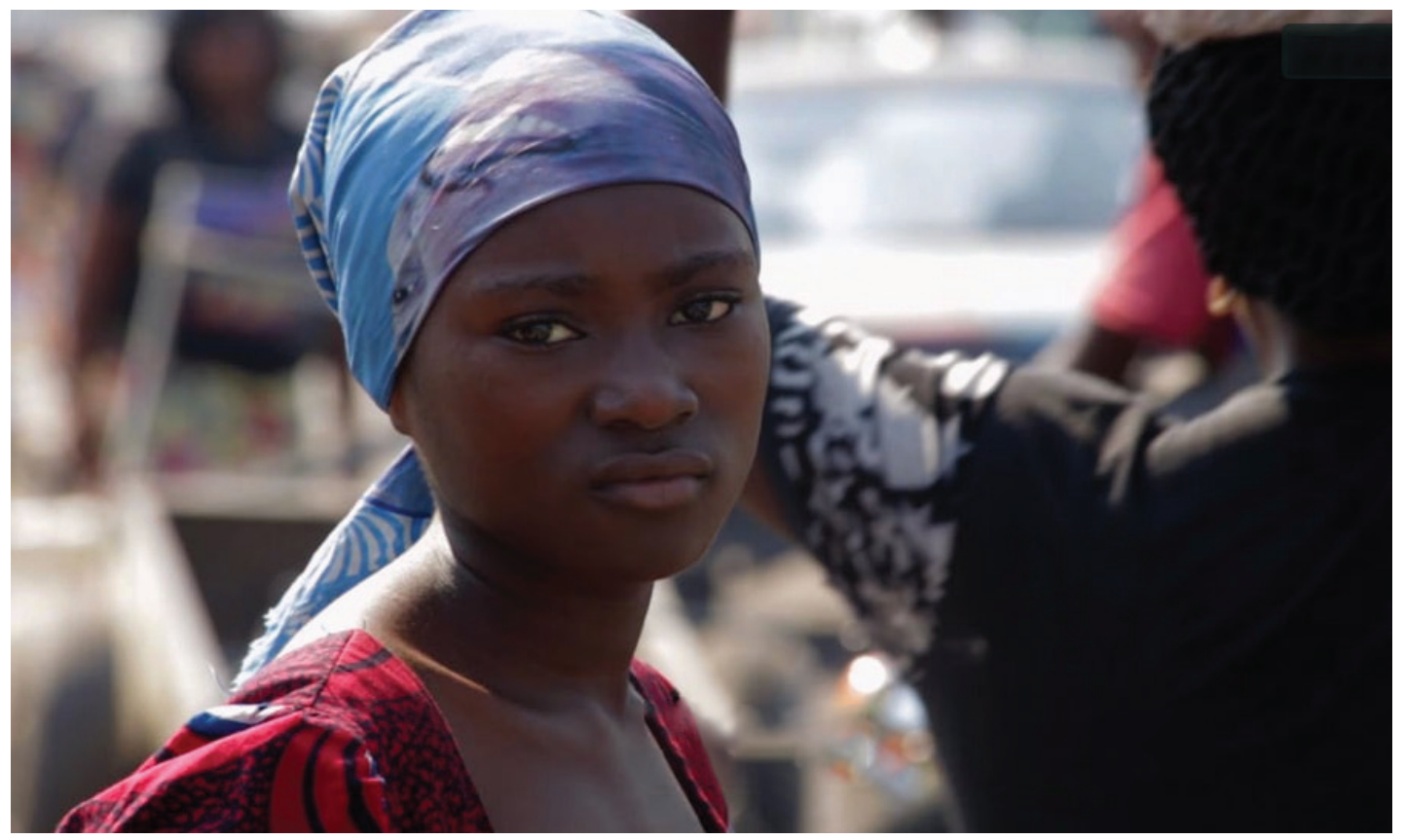

Figure 2. Trailer of the film La Belle at the Movies (Cecilia Zoppelletto, 2016) that documents some of the history of cinema in Kinshasa, including the rise of Billism. 
what he calls their 'cosmopolitan dress': '[t]his imaginary of American cinema was reflected in the way they dressed, in their suits, in the way in which they wore their mustaches - in the design of the mustache one could see the presence of the American actor, the white actor. ${ }^{24}$

Examples in other parts of Africa, where the figure of the cowboy has been appropriated include Nigeria in the 1930s. P.E.H. Hair reports that the 'Cowboy society' spread from Lagos to Kano as the two were connected by rail. 'Just as Lagos fashions and Lagos newspapers came up the railway to Kano,' Hair confirms, 'so did the Cowboy society.' It was characterised by typical modes of dress that included a red or green shirt, black trousers, shoes and stockings. ${ }^{25}$ It 'came' also to Enugu in the early 1940s and the Ebe village in 1948, where in Enugu cowboys sported black trousers, black shirt, shoes, stockings and a 'soldier's hat that was worn by the Nigeria Regiment.' This, Hair suggests, 'resemble[d] a sombrero.' The 'armament' part of the outfit was a gun in the belt that was 'either a toy gun firing explosive caps, or a wooden model of a gun carved in the village. ${ }^{26}$

In East Africa, the Beni dance incorporated cowboy features as exemplified in festivities that took place in Lamu in the 1950s. Terence Ranger quotes a report of the District Commissioner, where he observes that 'many of the costumes were cowboys (as could be expected),' underscoring the popularity of the cowboy. ${ }^{27}$ Not only was this popularity signified in the cowboy gear itself, but it also pointed to its source in the figure of the cowboy in the cinema. In the mid-1950s, Ranger reports, sailors and boatmen in Faza village, north of Lamu, emulated what they had learned from seeing the Beni in Lamu, and paraded in three lines, including a (rear) line where they wore 'black trousers, red shirts, and khaki hats, like cowboys. ${ }^{28}$ The appropriation of the cowboy figure in Africa, his behaviours and his accoutrements, is not always nor necessarily linked directly to personal experiences of 'going' to the cinema in some of the reports of how the cowboy was represented in personal or group behaviour and style. But it nevertheless 'speaks to' the influence of the cinema, however much it was filtered through the experiences of others, or through time and different parts of different regions. Moreover, the assimilation of the cowboy, as we see in the East African example that Ranger reports, is sometimes filtered through another cultural form, such as the Beni dance, that in itself incorporates complex elements, including music, and expounds meanings related to its colonial contexts.

The study of cinema history in Southern Africa has elicited perhaps more scholarship on the popularity of the cowboy figure than any other region. These historians include Charles Ambler, 
James Burns and Glenn Reynolds, whose scholarship focuses on mineworkers and cinema circuits in mining compounds in Southern Africa from the 1920s. Ambler's scholarship shows how thousands of mine workers in Northern Rhodesia (Zambia) were watching Hollywood films by the 1930s as part of the screening programme of films put on by mining companies. Burns's book-length study, Flickering Shadows: Cinema and Identity in Colonial Zimbabwe (2002), provides a detailed view of African audiences in the colonial period in Southern Rhodesia (Zimbabwe). Reynolds's Colonial Cinema in Africa: Origins, Images, Audiences (2015), dedicates a chapter to a discussion of the cowboy figure, 'recast[ing]' African audiences of the western genre, particularly mineworkers as 'active agents in constructing new forms of subjectivity. ${ }^{29}$ Each of these studies references the tendency amongst these audiences to use the name 'Jack' or a local variation (for example, 'Jeke' in Northern Rhodesia) for the cowboy hero. In her earlier study, Gutsche had already described the 'affection' on the mines for 'the mythical cowboy called “Jack” (no matter what his real name) and his always successful deeds of daring. ${ }^{30}$ Hortense Powdermaker, had also identified the same response in her anthropological study of African audiences in Northern Rhodesia in the 1950s. In Copper Town: Changing Africa, she describes audiences' responses to the 'cowboy film': '... men, women, and children rose to their feet in excitement, bending forward and flexing their muscles with each blow the cowboys gave. The shouting could be heard several miles away.' Comments such as 'Hmmm, Jack is very clever, he can fight them all' and 'Yes, this is the kind of Jack we want' pepper the responses. ${ }^{31}$ Her explanation for these audiences' enjoyment of the western is the release of 'pent up aggressions' and the shared pleasure in a crowd of a thousand or more brought together by the outdoor screenings organised in the mining

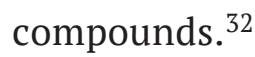

In South Africa, these screenings were first organised under the auspices of the Chamber of Mines primarily via the work of the American missionary Rev Ray Phillips who took up film as a means of intervening into the social fabric of mineworkers' urban experience and thereby 'moralising' their leisure time. Starting in the early 1920s, he worked with the Chamber of Mines in South Africa to screen films to migrant workers housed in mining compounds and established the Mines Compound Cinema Circuit. Hollywood films were distributed primarily through the distribution company, African Films Trust (AFT). Its owner, the entrepreneur I.W. Schlesinger, had established a vertically-integrated organisation from 1913, across production, exhibition and distribution. 
AFT distributed the films that Phillips screened on the mines. But Schlesinger's reach was much wider and AFT had an extensive distribution circuit that stretched to other parts of Africa, including Southern and Northern Rhodesia, where African workers on the copper mines saw the same films. ${ }^{33}$

The history of screenings for mineworkers raises two important issues that stretch beyond the present discussion but are nevertheless important to note. First, in Southern African territories missionaries and mine officials were concerned as to the effects of the cinema on African audiences particularly with regard to scenes of violence, romance and the representation of white women on screen. Phillips initially established a form of censorship through both the selection of films and cutting the films themselves. 'Every foot of these films,' he commented, 'is censored by us. ${ }^{34}$ These early means of censorship became more elaborate and in South Africa, following the promulgation of the Entertainments (Censorship) Act, 1931 and the establishment of the Union Board of Film Censors, all films had to be approved 'for exhibition to natives.' There were similar moves in other parts of the region. Not only are there useful comparisons to be made within the Southern African region, but it would be valuable to extend inter-regional research, in order to map the histories and forms of censorship measures following the coming of cinema across a wider proportion of African countries and regions.

The second issue to note is that of the reception of films. Most of the examples I have presented in this article make reference to questions of reception. Africans' film literacy became a major focus that led to several investigations, experiments, and forms of colonial film production specifically for African audiences. These include the conclusions that William Sellers, a health official in Nigeria in the 1920s, who was later to become the first director of the British Colonial Film Unit in 1939, published as 'Films for Primitive People. 35 Other experiments include the Bantu Educational Kinema Experiment (BEKE) established in 1935, following an enquiry into 'the effect of the Copper Mines of central Africa upon native society and the work of the Christian missions' under the auspices of the International Missionary Council and led by the missionary, John Merle Davis. One of the BEKE’s aims was to restrict the circulation of commercial films and it was therefore in a sense, as Burns proposes, a form of 'proactive censorship. ${ }^{36}$ Investigations into African audiences' reception of film through circuits and networks of missionaries, mining officials, colonial officials and others such as anthropologists, also provide fertile ground for comparative research and scholarship. While scholars have achieved some exemplary, foundational work on the experiments I have cited, less has been done between different African regions, particularly across former colonial boundaries. 


\section{Conclusions}

Three conclusions arise from this discussion. First, the western genre and its exhibition across Africa has had a major impact on the formation of identities on the continent. This suggests that there is mileage to be gained in a focus on this genre specifically, but it suggests further that the same could be true of other genres. The gangster genre for example, is clearly indicated as one that would be important to focus on, especially since there are overlaps between the western and the gangster genres in relation to the sociology of gangs themselves, including their names, clothing styles and behaviours. The influence of each of these genres in the production of 'outlaw' characters in different socio-political contexts across different parts of Africa could potentially open up new cinematic histories on genre. Apart from anything else, questions of gender and the production of masculinities would be crucial to examine.

Second, there is a strong case to be made for identifying where the cinematic cowboy was, and possibly still is, historically appropriated in different parts of Africa. Each instance I have identified reveals the local particularities of identities forged on the basis of the genre's influence and transformed into 'hybridised' renditions, without losing their referentiality to the source from which they derive. Further research across Africa would be fruitful and would add to the growing archive of material on the western and its impact in Africa.

Some of the case studies I have excavated suggest that adopting a regional purview of the influence of the western could be useful. This may not always be as simple as it seems. In the case of Southern Africa, this is already indicated in relation to historical connections, such as the means of distribution and exhibition across the region being largely in the hands of a single provider, the Schlesinger Organisation. Also, economic ties, particularly on the basis of the movement of migrant workers across Southern Africa, many of whom comprised audiences of westerns in the mining compounds in which they were housed, suggest there is comparative value in considering this region as a whole. Burns, in particular, has shown how a wider contextual purview can be useful, in that he followed up his first book on colonial Zimbabwe with a second book that examined audiences across the British Empire. Similarly the recent volume, The Western in the Global South (2015), takes the 'global south' as an umbrella for a range of case studies specifically on the western genre. These framings extend beyond the national and the regional and thus open up new perspectives across broader fields beyond the African continent, while maintaining some form of connection between different instances. A pan-African purview could equally provide such a wider framing. 
Third, the study of instances where the western has influenced the construction of identities raises crucial questions about method since in each instance that I have cited, scholars adopt different methods to greater or lesser extents. This in part reflects the disciplines in which they are trained but also reflects the circumstances of the research itself. The incorporation of survey materials, oral histories and interviews, produces particularly enlightening accounts. Fair's scholarship on Tanzania is an excellent exemplar, where the combination of many personal accounts with 'official' records and 'uncollected holdings' provides a 'lived' sense of the multiple experiences of the cinema from which to build a history. Gondola's and Moorman's interviews represent further important examples. Access to accounts of personal experience is not always a simple matter and the costs of creating these can be high. It is worth noting that there are oral history collections that could be researched further for memories of cinema and its influence.

The initial forays this article makes into researching the influence of the cinematic cowboy on African audiences suggest that this focus has the potential to create new histories that can extend comparative, interdisciplinary approaches to show how African audiences appropriated cinematic identities based on the western genre to their own ends. What those ends were or became is the stuff that future research, comparative or otherwise, will hopefully elaborate.

With grateful thanks to Thunnis van Oort and Jessica Whitehead. Special thanks to Emma Sandon.

\section{Notes}

1 The four cowboys, apart from Glover, are played by filmmakers Elia Suleiman and Zeka Laplaine; Jean-Henri Roger, professor, director and actor who died in 2012; and Ferdinand Batsimba, theatre and film writer and director. Batsimba directed a short film entitled African Western (1992). For a further discussion of Death in Timbuktu, see Dayna Oscherwitz, "In the Crossfire: Africa, Cinema, and Violence in Abderrahmane Sissako's Bamako (2006)," in The Western in the Global South, ed. MaryEllen Higgins, Rita Keresztesi and Dayna Oscherwitz (Oxon and New York: Routledge, 2015), 81-95. For a discussion of Bamako, other films and the western, see Tsitsi Jaji, "Cassava Westerns: Theorizing the Pleasures of Playing the Outlaw in Africa”, in The Western in the Global South, 24-41. On the use of colour in Bamako see Jacqueline Maingard, “Screening Africa in Colour: Abderrahmane Sissako’s Bamako,” Screen 51, no. 4 (2010), 397-403. See also Jacqueline Maingard, “African Cinema and Bamako (2006): Notes on Epistemology and Film Theory," Critical African Studies 5, no. 2 (2013), 103-113. 
“Abderrahmane Sissako’s Film Lesson,” 6 March 2003, http://africultures.com/abderrahmanesissakos-film-lesson-5671/?utm_source=newsletter\&utm_medium=email\&utm_campaign=476. The figure of the cinematic cowboy and/or references to the western genre are represented in other African films including Mustapha Alassane's short western, Le retour d'un aventurier (1966), Djibril Diop Mambety's Hyénes (1992) and Ousmane Sembène’s Xala (1972).

4 Standard and Diggers News, 6 April 1895, quoted in Thelma Gutsche, The History and Social Significance of Motion Pictures in South Africa (Cape Town: Howard Timmins, 1972), 8, no 10.

5 Gutsche, Motion Pictures in South Africa, ibid.

6 Ibid., 9.

7 See Daniel Biltereyst and Philippe Meers, "New Cinema History and the Comparative Mode: Reflections on Comparing Historical Cinema Cultures," Alphaville: Journal of Film and Screen Media 11 (2016), 13-32, especially 20-25, where the authors tabulate and discuss their four modes of comparison.

8 See Bill Nasson, “'She Preferred Living in a Cave with Harry the Snake-catcher': Towards an Oral History of Popular Leisure and Class Expression in District Six, Cape Town, c.1920-1950,” in Holding Their Ground: Class, Locality and Culture in 19th and 20th Century South Africa, ed. Phil Bonner, Isabel Hofmeyr and Deborah James (Johannesburg: Ravan Press and Witwatersrand University Press), 285-309; and Jacqueline Maingard, “Cinemagoing in District Six, Cape Town, 1920s to 1960s: History, Politics, Memory," Memory Studies 10, no. 1 (2017), 17-34.

9 See Jaji, “Cassava Westerns,” for a discussion of the 'outlaw’ figure in films and literature.

10 Laura Fair, Reel Pleasures: Cinema Audiences and Entrepreneurs in Twentieth-Century Urban Tanzania (Athens: Ohio University Press, 2018), 145.

11 Fair, Reel Pleasures, 167.

12 Ibid., 145.

13 Ibid., 169-170. Like Fair, James Burton notes the removal of youth from the cities: "one of the early acts of the 'responsible' TANU-dominated [Tanganyika African National Union] government, installed in late 1959, was to introduce schemes aimed at removing un- and under-employed Africans from the capital," see James Burton, "Urchins, Loafers and the Cult of the Cowboy: Urbanization and Delinquency in Dar es Salaam, 1919-61," Journal of African History 42 (2001), 215. See also James Brennan, “Democratizing Cinema and Censorship in Tanzania, 1920-1980," The International Journal of African Historical Studies, 38, no. 3 (2005), 481-511, especially 506-509 on the censoring of commercial films and opinions on 'cowboy' films. 
14 Ch. Didier Gondola, Tropical Cowboys: Westerns, Violence, and Masculinity in Kinshasa (Bloomington: Indiana University Press, 2016), 74.

15 Gondola, Tropical Cowboys, 76.

16 Ibid., 79.

17 Ibid., 78.

18 Ibid., 77.

19 Ibid., 59. Also see 59-64, for historical detail of African audiences' access to screenings in cinemas.

20 Ibid., 66.

21 Ibid. The photographer Jean Depara took photographs of Bills, including some of female Bills, that can be seen at: https://edition.cnn.com/2015/12/08/africa/gallery/kinshasa-cowboys-bills/index.html; and https://www.boumbang.com/jean-depara/. Cecilia Zoppelletto’s film La Belle at the Movies (2015) documents some of the history of cinema in Kinshasa ('La Belle') including the rise of Billism. The trailer can be seen and the film purchased for streaming at: https://vimeo.com/ondemand/labelleatthemovies.

22 Marissa Moorman, "Of Westerns, Women, and War: Re-Situating Angolan Cinema and the Nation,” Research in African Literatures 32, no. 3 (2001), 104.

23 Moorman, “Of Westerns, Women, and War,” 103.

24 Ibid., 108.

25 P.E.H. Hair, “The Cowboys: A Nigerian Acculturative Institution (Ca. 1950)," History in Africa, 28 (2001), 89.

26 Hair, "The Cowboys," 84.

27 Terence Ranger, Dance and Society in Eastern Africa, 1890-1970: The Beni Ngoma (Berkeley and Los Angeles: University of California Press, 1975), 145.

28 Ranger, Dance and Society, 146.

29 Glenn Reynolds, Colonial Cinema in Africa: Origins, Images, Audiences (Jefferson, North Carolina: McFarland and Company, Inc., 2015), 129.

30 Gutsche, Motion Pictures in South Africa, 379 n.60.

31 Hortense Powdermaker, Coppertown: Changing Africa, The Human Situation on the Rhodesian Copperbelt (New York and Evanston: Harper and Row, 1962), 258.

32 Powdermaker, Coppertown, 261.

33 See James Burns, "The Western in Colonial Southern Africa," in The Western in the Global South, 11-23, for a useful overview of the western in the Southern African region. Further useful references to the adoption of cowboy-related names and accoutrements in South Africa include comments on the abaqhafi in Natal in 
Absolom Vilakazi, Zulu Transformations (Pietermaritzburg: University of Natal Press, 1962), 76-78; and the autobiographical memoirs in Es'kia Mphahlele, Down 2nd Avenue (London: Pan Macmillan, 2004 [1959]). See also Clive Glaser, Bo-Tsotsi: The Youth Gangs of Soweto, 1935-1976 (Oxford: James Currey, 2000).

34 Ray Phillips, The Bantu are Coming: Phases of South Africa's Race Relations (London: Student Christian Movement, 1930), 151. See also Jacqueline Maingard, South African National Cinema (London and New York: Routledge, 2007), 71.

35 William Sellers, “Films for Primitive Peoples,” Documentary News Letter 2, no. 9 (September 1941), 173-174. 36 James Burns, Flickering Shadows: Cinema and Identity in Colonial Zimbabwe (Athens: Ohio University Press, 2002), 27. See the 'BEKE' entry on the website of the 'Colonial Film: Moving Images of the British Empire' research project, which includes a comprehensive list of relevant publications including Rosaleen Smyth (1979) and Glenn Reynolds (2009), http://www.colonialfilm.org.uk/production-company/bekefilm. See also Tom Rice, Films for the Colonies: Cinema and the Preservation of the British Empire, (Oakland, California: University of California Press, 2019), 35-43; and Aboubakar Sanogo, “Colonialism, Visuality and the Cinema: Revisiting the Bantu Educational Kinema Experiment,” in ed. Lee Grieveson and Colin MacCabe, Empire and Film (London: Palgrave Macmillan, 2011), 227-246.

\section{Biography}

Jacqueline Maingard is Reader in Film at the University of Bristol, and Honorary Research Associate in the Archive and Public Culture Research Initiative, University of Cape Town. Author of South African National Cinema (Routledge, 2007), she has published on film and history in Africa in various journals and volumes, including Journal of Southern African Studies, Memory Studies and Screen. She is currently completing a monograph on black cinema audiences in South Africa, 1920s to 1960s. She is also leading a research project on colonial film archives in Britain. 


\section{TMG Journal for Media History}

Volume 23 No $(1 / 2) / 2020$

\section{DOI}

https://dx.doi.org/10.18146/tmg.796

\section{PUBLISHER}

Netherlands Institute for Sound and Vision

\section{COPYRIGHT}

Each article is copyrighted (c) by its author(s) and is published under license from the author(s). When a paper is accepted for publication, authors will be requested to agree with the Creative Commons Attribution 4.0 International License. 